\title{
Impact of urbanization on functional diversity in macromycete communities along an urban ecosystem in Southwest Mexico
}

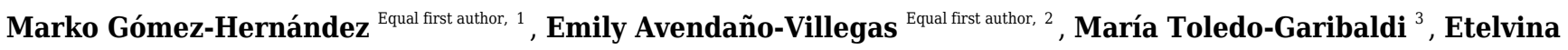 \\ Gándara ${ }^{\text {Corresp. } 4}$ \\ ${ }^{1}$ CONACYT-CIIDIR Unidad Oaxaca, Instituto Politécnico Nacional, Santa Cruz Xoxocotlán, Oaxaca, Mexico \\ 2 CIIDIR Unidad Oaxaca, Instituto Politécnico Nacional, Santa Cruz Xoxocotlán, Oaxaca, Mexico \\ 3 Daniels Faculty of Architecture, Landscape and Design, University of Toronto, Toronto, Canada \\ ${ }^{4}$ Facultad de Ciencias Biológicas, Benemérita Universidad Autónoma de Puebla, Puebla, Puebla, Mexico \\ Corresponding Author: Etelvina Gándara \\ Email address: etelvina.gandara@correo.buap.mx
}

Macromycetes are a group of fungi characterized by the production of fruit bodies and are highly relevant in most terrestrial ecosystems as pathogens, mutualists, and organic matter decomposers. Habitat transformation can drastically alter macromycete communities and diminish the contribution of these organisms to ecosystem functioning, however, knowledge on the effect of urbanization on macrofungal communities is scarce. Diversity metrics based on functional traits of macromycete species have shown to be valuable tools to predict how species contribute to ecosystem functionality since traits determine the performance of species in ecosystems. The aim of this study was to assess patterns of species richness, functional diversity, and composition of macrofungi in an urban ecosystem in Southwest Mexico, and to identify microclimatic, environmental, and urban factors related to these patterns in order to infer the effect of urbanization on macromycete communities. We selected four oak forests along an urbanization gradient and established a permanent sampling area of 0.1 ha at each site. Macromycete sampling was carried out every week from June to October 2017. The indices used to measure functional diversity were functional richness (FRic), functional divergence (FDig), and functional evenness (FEve). The metric used to assess variation of macrofungal ecological function along the study area was the functional value. We recorded a total of 134 macromycete species and 223 individuals. Our results indicated a decline of species richness with increased urbanization level related mainly to microclimatic variables, and a high turnover of species composition among study sites, which appears to be related to microclimatic and urbanization variables. FRic decreased with urbanization level, indicating that some of the available resources in the niche space within urbanized sites are not being utilized. FDig increased with urbanization, which suggests a high degree of niche differentiation amona macromvcete species within communities in urbanized areas. FEve Peerj reviewing PDF | (2021:03:59452:2:0:NEW 22 Auǵ 2021) 
did not show notable differences along the urbanization gradient, indicating few variations in the distribution of abundances within the occupied sections of the niche space. Similarly, the functional value was markedly higher in the less urbanized site, suggesting greater performance of functional guilds in that area. Our findings suggest that urbanization has led to a loss of macromycete species and a decrease in functional diversity, causing some sections of the niche space to be hardly occupied and available resources to be under-utilized, which could, to a certain extent, affect ecosystem functioning and stability. 
1 Impact of urbanization on functional diversity in macromycete communities along an 2 urban ecosystem in Southwest Mexico

3 Marko Gómez-Hernández Equal first autor, 1, Emily Avendaño-Villegas Equal first autor, 2, María Toledo4 Garibaldi $^{3}$, Etelvina Gándara ${ }^{4}$

$6 \quad{ }^{1}$ CONACYT-CIIDIR Unidad Oaxaca, Instituto Politécnico Nacional. Santa Cruz Xoxocotlán, 7 Oaxaca, Mexico.

8 2CIIDIR Unidad Oaxaca, Instituto Politécnico Nacional. Santa Cruz Xoxocotlán, Oaxaca, 9 Mexico.

$10{ }^{3}$ Daniels Faculty of Architecture, Landscape and Design, University of Toronto. Toronto, 11 Canada.

$12{ }^{4}$ Facultad de Ciencias Biológicas. Benemérita Universidad Autónoma de Puebla, Puebla, Puebla, 13 Mexico.

Corresponding author:

Etelvina Gándara ${ }^{4}$

17 E-mail address: etelvina.gandara@gmail.com 
24

25

26

27

\section{Abstract}

Macromycetes are a group of fungi characterized by the production of fruit bodies and are highly relevant in most terrestrial ecosystems as pathogens, mutualists, and organic matter decomposers. Habitat transformation can drastically alter macromycete communities and diminish the contribution of these organisms to ecosystem functioning, however, knowledge on the effect of urbanization on macrofungal communities is scarce. Diversity metrics based on functional traits of macromycete species have shown to be valuable tools to predict how species contribute to ecosystem functionality since traits determine the performance of species in ecosystems. The aim of this study was to assess patterns of species richness, functional diversity, and composition of macrofungi in an urban ecosystem in Southwest Mexico, and to identify microclimatic, environmental, and urban factors related to these patterns in order to infer the effect of urbanization on macromycete communities. We selected four oak forests along an urbanization gradient and established a permanent sampling area of 0.1 ha at each site.

Macromycete sampling was carried out every week from June to October 2017. The indices used to measure functional diversity were functional richness (FRic), functional divergence (FDig), and functional evenness (FEve). The metric used to assess variation of macrofungal ecological function along the study area was the functional value. We recorded a total of 134 macromycete species and 223 individuals. Our results indicated a decline of species richness with increased urbanization level related mainly to microclimatic variables, and a high turnover of species composition among study sites, which appears to be related to microclimatic and urbanization variables. FRic decreased with urbanization level, indicating that some of the available resources in the niche space within urbanized sites are not being utilized. FDig increased with urbanization, which suggests a high degree of niche differentiation among macromycete species within communities in urbanized areas. FEve did not show notable differences along the urbanization gradient, indicating few variations in the distribution of abundances within the occupied sections of the niche space. Similarly, the functional value was markedly higher in the less urbanized site, suggesting greater performance of functional guilds in that area. Our findings suggest that urbanization has led to a loss of macromycete species and a decrease in functional diversity, causing some sections of the niche space to be hardly occupied and available resources to be under-utilized, which could, to a certain extent, affect ecosystem functioning and stability. 
54

55

56

57

58

59

60

61

62

63

64

\section{Introduction}

Urbanization alters biogeochemical cycles worldwide, contributes to the loss of biodiversity, and has been identified as one of the main causes of species extinctions (McKinney, 2006; Barrico et al., 2012). A broad definition by Niemelä (1999) states that urbanization is the process leading to the increase of densely populated areas characterized by industrial, business, and residential districts. For the past seven decades there has been an exponential growth of urban areas due to population growth and migration (UN, 2018). Nowadays, ca. 4.2 billion people live in urban areas worldwide, and this trend is expected to continue, estimating that by 2045 there will be 6 billion people living in cities, representing almost $70 \%$ of the world's population (UN, 2014, 2018; McPhearson et al., 2016). Currently, 82\% of the population in Latin America is concentrated in urban areas and megacities (i.e., urban areas with more that 10 million people), and Mexico follows the same pattern with $83 \%$ of its population of ca. 130 million people living in urban areas (MacGregor-Fors \& Ortega-Álvarez, 2013; Worldmeters, 2020).

Urban areas have been recognized as urban ecosystems composed by anthropogenically built environments and natural or semi-natural areas containing high proportions of non-native plant and animal species (McDonnell \& Pickett, 1990; Cousins et al., 2003). Studies in urban areas worldwide have shown that urbanization causes declines in the number of native species and there is a decrease of human influence on diversity from city centers out towards wild areas. Thus, communities of groups like birds, plants, insects, and fungi within cities differ from surrounding communities in non-urban areas (Niemelä, 1999; Grimm et al., 2008; MacGregorFors et al.,2015; Avis et al., 2016). Specifically, fungal communities are highly susceptible to habitat loss and can be extremely affected by urbanization, producing a decrease in species richness and changes in species composition among habitat conditions, determined mainly by microclimate, atmospheric pollutants, and factors related to substratum availability and vegetation structure (Newbound, McCarthy \& Lebel, 2010; MacGregor-Fors et al.,2015; Avis et al., 2016; Gómez-Hernández, Ramírez-Antonio \& Gándara, 2019).

Fungi comprise one of the most diverse groups in the world (ca. 5.1 million of species) and include both micromycetes (microscopic fungi) and macromycetes (macroscopic fungi) (Blackwell, 2011). Macromycetes are fungi that produce fruit bodies visible to the naked eye and are of vital importance in most terrestrial non-urban and urban ecosystems worldwide (Dighton, 
84 85

2003). Pathogenic macromycetes can act as natural regulators of plant and animal populations, thus affecting the structure of communities and species productivity (Hansen \& Stone, 2005; Deacon, 2006). Saprotrophic and wood-decaying macrofungal species are the main organisms involved in the degradation of organic matter and play a fundamental role in soil formation and nutrient cycling (Lodge \& Cantrell, 1995; Deacon, 2006; Mueller \& Bills, 2004; Lonsdale, Pautasso \& Holdenrieder, 2008). Ectomycorrhizal fungi establish symbiotic associations with plants, facilitating plant uptake of nutrients such as phosphorus and nitrogen in exchange for photosynthetically fixed carbon (Hall, Yun \& Amicucci, 2003; Egli, 2011). Nevertheless, macromycetes are highly vulnerable to environmental and microclimatic changes, and habitat modification can impact macrofungal diversity, distribution, and fruit body production (O'Dell, Ammirati \& Schreiner, 1999; Brown, Bhagwat \& Watkinson, 2006; Durall et al., 2006).

Evaluating variations in species richness and composition along urban landscapes is of importance to identify anthropogenic factors affecting groups of organisms, like macromycetes, that can be of great importance for ecosystems, but susceptible to environmental changes (Deacon, 2006). It is widely known that species have different roles in ecosystem processes and respond differently to environmental pressures due to their particular set of functional traits. Traditional diversity metrics based solely on the number of species can be uninformative because all species are considered as equivalent units (Flynn et al., 2009; Diaz \& Cabido, 2001; Hooper et al., 2002). Consequently, there is wide interest in incorporating metrics based on functional traits to research on species diversity and ecosystem functionality (Crowther et al., 2014; Koide, Fernandez \& Malcom, 2014; Aguilar-Trigueros et al., 2015; Pringle, Vellinga \& Peay, 2015; Caiafa et al., 2017). Functional traits are quantifiable, morphological, biochemical, physiological, phenological or reproductive characteristics which affect the performance or fitness of organisms under different environmental conditions (response traits) or determine how species contribute to ecosystem functionality (effect traits) (McGill et al., 2006; Cadotte et al., 2009; Tsianou \& Kallimanis, 2016; Caiafa et al., 2017). Although there is a recognized need to assess macromycete diversity patterns using a trait-based approach and to understand how urbanization affects macrofungal communities, studies on macromycete functional diversity are scarce. This is particularly true for urban ecosystems where the fungal diversity may be compromised, and therefore, also their role as mutualists, pathogens, and organic matter 
114 decomposers within native vegetation remnants and green spaces in urbanized areas (Newbound, 115 McCarthy \& Lebel, 2010).

116 In Mexico, the state of Oaxaca is the most biologically and culturally diverse region. Currently, $11777 \%$ of Oaxaca's ca. 3900000 people live in cities, and estimates indicate a population increase 118 of $10.9 \%$ by 2030 (Flores-Villela \& Gerez, 1994; CONAPO, 2014; INEGI, 2015b). In this 119 context, the aims of our study were to evaluate patterns of macromycete species richness, 120 diversity, functional diversity, and species composition along an urban ecosystem in a 121 heterogeneous landscape in central Oaxaca, Mexico, and to identify the microclimatic, 122 environmental and urban factors related to these patterns. We related these aims to the following 123 hypotheses: (1) patterns of species richness and diversity are positively correlated, and both 124 metrics decrease with increasing urbanization, (2) humidity and temperature are the main drivers 125 of species richness variation along the urbanization gradient, and also are related with the 126 turnover of species composition, (3) the composition of macromycete species highly differs 127 between urbanized and non-urbanized sites, (4) urbanization variables negatively affect 128 functional diversity, and (5) different types of functional traits display different patterns along 129 the urbanization gradient.

\section{Materials \& Methods}

Study area and sites

The study was conducted in the region of Valles Centrales in Oaxaca, Mexico. This region is found in central Oaxaca, between $18^{\circ} 40^{\prime}-15^{\circ} 39^{\prime} \mathrm{N}$ and $93^{\circ} 52^{\prime}-98^{\circ} 33^{\prime} \mathrm{W}$, with an elevation ranging from 1010 to $2600 \mathrm{~m}$. The region encompasses 121 municipalities and covers an area of ca. $12000 \mathrm{~km}^{2}$. The mean annual temperature in Valles Centrales is $22{ }^{\circ} \mathrm{C}$, and mean annual precipitation is $1550 \mathrm{~mm}$ (INEGI, 2017).

Three oak forest areas were selected in localities surrounding Oaxaca city: Benito Juarez National Park (Site 1) at 2254 masl, Las Antenas (Site 2) at 1711 masl, Santo Domingo Tomaltepec (Site 3) at 1678 masl; and the Cerro el Fortín Ecological Reserve (Site 4), an area within Oaxaca city at 1769 masl. At each site, two $100 \mathrm{~m}$ x $20 \mathrm{~m}$ areas were delimited at least 
$14230 \mathrm{~m}$ away from the forest edge. Within each of these areas, five permanent $10 \mathrm{~m} \times 10 \mathrm{~m}$ plots

143 were haphazardly established to cover a sampling area of 0.1 ha.

144 Authorization to carry out field work in Cerro del Fortin was given by Directorate of Natural

145 Resources and Sustainable Development of Oaxaca. Authorizations in Benito Juarez National

146 Park, Las Antenas, and Santo Domingo Tomaltepec were given verbally by local authorities.

\section{Explanatory variables}

148 A total of 15 microclimatic, environmental, vegetation and urbanization variables were used as

149 explanatory variables in this study. Each sampling day, air humidity $(\%)$, air temperature $\left({ }^{\circ} \mathrm{C}\right)$,

150 soil humidity $(\%)$, and soil temperature $\left({ }^{\circ} \mathrm{C}\right)$ at the center of each plot were recorded at the four

151 study sites. Slope $\left({ }^{\circ}\right)$, and soil and stoniness cover $(\%)$ were measured once at every plot. Litter

152 depth $(\mathrm{cm})$ was recorded in each plot at the beginning, middle, and end of the sampling season.

153 Woody plants with a diameter $\geq 5 \mathrm{~cm}$ at $1.3 \mathrm{~m}$ above the ground were identified and counted,

154 and their diameter and height were measured. These latter data were used to calculate three

155 variables representing vegetation structure which served as explanatory variables: density

156 (individuals ha- $\left.{ }^{-1}\right)$, basal area $\left(\mathrm{m}^{2} \mathrm{ha}^{-1}\right)$, and mean tree height $(\mathrm{m})$.

157 To describe the urbanization gradient along our study area, we selected eight variables as

158 indicators of land-use intensity and disturbance. Urbanization gradients are typically represented

159 by a transect running from an urban core out to rural hinterlands, by measures of population

160 density (Conway \& Hackworth, 2007), land cover (McDonnell \& Hahs, 2008), or land use

161 factors (Ortega-Álvarez, Rodríguez-Correa \& MacGregor-Fors, 2011). In this study we included

162 measures of land cover and population density. Urbanization variables were screened for

163 collinearity using a Pearson correlation matrix to identify any high correlations among them.

164 After removing the correlated variables, we retained five: extent of built area $\left(\mathrm{m}^{2}\right)$, extent of crop

165 area $\left(\mathrm{m}^{2}\right)$, population density (individuals ha-1), extent of areas with introduced vegetation $\left(\mathrm{m}^{2}\right)$,

166 and street and road length $(\mathrm{m})$. To determine the urbanization gradient in the study area, the

167 explanatory variables were measured within a circular buffer of $3 \mathrm{~km}$ radius from the center of

168 each sampling site. The $3 \mathrm{~km}$ radius was selected to allow a considerable distance among buffer

169 boundaries. All urbanization variables were derived from land-use data layers and census data

170 obtained from the National Institute of Statistics and Geography (INEGI, 2013; INEGI, 2015a), 
171 and the total values of the variables were calculated per buffer using zonal statistics in ArcGIS

17210.4 (ESRI Inc., 2016).

173 Macromycete sampling, species richness, diversity, and species composition

174 Sampling was carried out weekly in each plot at every study site throughout the rainy season 175 (June to October) of 2017. The criterion used for macromycete sampling was to collect all the 176 fruit bodies visible to the naked eye. Fruit bodies of the same species within a $50 \mathrm{~cm}$ radius, 177 caespitose growth, fairy rings, and fruit bodies of the same species growing on the same log or 178 branch were recorded as a single collection unit, and abundance was estimated as the number of 179 collection units (adapted from Schmit, Murphy \& Mueller, 1999). Hereafter, for practical 180 purposes, collection units will be referred to as individuals. Specimens were separated at the 181 species level based on their micromorphological and macromorphological characteristics, and unidentified taxa were classified as numbered morpho-species using a higher taxonomic level approach. Specimens were identified using taxonomic keys and guides (Guzmán 1977; Largent \& Thiers 1977; Largent, Johnson \& Watling 1977; Breitenbach \& Kränzlin 1984; Breitenbach \& Kränzlin 1986; Largent 1986; Pegler 1986; Largent \& Baroni 1988; Breitenbach \& Kränzlin 186 1991).

187

Species richness (Sobs) was estimated as the total number of species observed in each study site. Macrofungal diversity was calculated with the true diversity index of first order $\left({ }^{1} \mathrm{D}\right)$ using the multiplicative diversity decompositions of the effective number of species (Jost, 2006; Jost, 2007) by means of the entropart package in R v. 3.4.2 (R Core Team, 2017). The species richness estimator Jacknife 2 was used to determine how complete were the inventories of species recorded in every study site, and the turnover of species composition among study sites was assessed with the Chao-Jaccard similarity index (Chao et al. 2005). Both calculations were performed in EstimateS 9.1.0 (Colwell, 2013).

\section{Functional diversity and functional value indexes}

To calculate functional diversity of macromycetes, we selected five morphology-related functional traits and arranged them into three trait groups: 1) morphological traits (fruit body texture, hymenium type, pileus diameter), 2) reproductive traits (spore size and shape), and 3) all the traits together (Caiafa et al., 2017). Texture was classified as delicate, jelly-like, fleshy, 
200 gristly, coriaceous, carbonaceous or woody. Hymenium types were classified as: pores, teeth, 201 gills, daedaloid, apothecia, perithecia, cleistothecia, acosctromata, smooth, hysterothecia, gleba, 202 or stings (Ulloa \& Hanlin, 2012). For each species, we measured 40 spores; their size was 203 estimated from mean length and breadth using the revolution ellipsoid, and spore shape was 204 calculated as the length/width ratio (Gross, 1972).

205 The indices used to assess functional diversity in the four study sites were: functional richness 206 (FRic), which represents the space filled by species in a convex hull volume of functional traits; 207 functional divergence (FDig), representing the degree of niche differentiation as a result of 208 functional trait dispersion in a community; and functional evenness (FEve), which indicates how 209 homogeneously the abundance of characters is distributed in the trait space (Mason et al., 2005; Villéger, Mason \& Mouillot, 2008; Mouchet et al., 2010). All the functional diversity indexes were calculated for the three trait groups with the FD package in R v. 3.4.2 (R Core Team, 212 2017).

213 We calculated the functional value index proposed by Avis et al. (2016) to assess the variation of macromycete ecological function along the urbanized gradient. For this, the recorded species were classified as ectomycorrhizal, saprotrophic, and parasitic fungi (based on authors

216 knowledge and the specialized literature mentioned above) and a functional value was assigned 217 to each functional guild (4, 3 and 1, respectively) based on the number of ecosystem services 218 they provide (see Table 2.1 of Dighton, 2003; Tables S3a \& S3b of Avis et al., 2016). The 219 functional value was calculated for each of the 40 plots in the study area using the formula:

220 Site Simple $=\left[F_{\mathrm{EcM}} \times \ln \left(\#\right.\right.$ species $\left._{\mathrm{EcM}}+1\right]+\left[F_{\mathrm{Sap}} \times \ln \left(\#\right.\right.$ species $\left._{\mathrm{Sap}}+1\right]+\left[F_{\mathrm{Par}} \times \ln (\#\right.$ species Par $221+1]$

222 Where $F$ is the functional value assigned to each guild, \#species is the number of species, EcM is ectomycorrhizal fungi, Sap is saprotrophic fungi, and Par is parasitic fungi.

\section{Statistical analyses}

225 Prior to statistical analyses, the assumption of normality was assessed performing Shapiro-Wilk tests (Shapiro \& Wilk, 1965), and data were transformed when necessary, using Log, squareroot, and reciprocal transformations. A two-sample Kolmogorov-Smirnov test was performed to 
228 define differences between patterns of species richness and diversity data obtained in the study

229 sites; the null hypothesis for this test is that both data samples have identical distributions

230 (Marsaglia, Tsang \& Wang, 2003). The relationship between the number of species and the

231 values of diversity was assessed with a linear regression analysis.

232 A regression tree analysis was performed to determine how the main explanatory variables affect

233 the variation of macromycete species richness in the study area (De'ath \& Fabricius, 2000). The

234 correlation between species richness and explanatory variables was determined using the

235 Spearman's rho correlation coefficient. All the microclimatic, environmental and vegetation

236 structure variables were included in both Spearman correlation and regression tree analyses.

237 We performed canonical correlation analyses (CCA) to understand macromycete distribution

238 with respect to the set of environmental, microclimatic and urbanization variables. Forward

239 selection was used for ranking explanatory variables in importance, and their statistical

240 significance was tested using the Monte Carlo permutation test (Legendre \& Legendre, 2012).

241 The relationship between every functional diversity index (FRic, FEve, FDig) and each

242 urbanization variable, between every functional diversity index calculated by trait group (i.e., all

243 traits, morphological traits, reproductive traits) and the level of urbanization along the study area,

244 and between the functional value and macromycete species richness was analyzed by fitting

245 linear and polynomial regressions using the Akaike information criterion (AIC) (Akaike, 1973)

246 to select the best models.

247 We used one-way analyses of variance (ANOVA) to determine differences among study sites

248 with regard to the functional value. To identify pairs of means that differed from each other, we

249 used Tukey's HSD tests with 95\% confidence level.

250 All statistical analyses were performed in R Studio v. 3.4.2 (R Core Team, 2017).

251

252 Results

253 Macromycete species richness and diversity 
254 A total of 223 individuals belonging to 134 species, 52 genera, 35 families, 16 orders, 6 classes,

255 and 2 phyla were recorded in the study area (Supplemental file 1). The site with the highest

256 urbanization level was Cerro el Fortín Ecological Reserve (Site 4), followed by Santo Domingo

257 Tomaltepec (Site 3), Las Antenas (Site 2), and Benito Juarez National Park (Site 1). Benito

258 Juárez National Park showed the highest number of species, diversity, and abundance (Site 1,

259 Sobs $=77,{ }^{1} \mathrm{D}=62.78$, individuals $\left.=116\right)$, followed by Las Antenas (Site 2, Sobs $=34,{ }^{1} \mathrm{D}=$

260 29.11, individuals $=46)$, Santo Domingo Tomaltepec (Site 3, Sobs $=22,{ }^{1} \mathrm{D}=19.7$, individuals $=$

261 31), and Cerro el Fortín Ecological Reserve (Site 4, Sobs $=21,{ }^{1} \mathrm{D}=18.57$, individuals $=30$ ).

262 Patterns of species richness and diversity along the urbanization gradient did not differ

263 significantly (Kolmogorov-Smirnov test, $\mathrm{D}=0.5, \mathrm{P}=0.69$ ), and were positively correlated

264 (Linear regression, $\mathrm{F}=34.19, \mathrm{r} 2=0.99, \mathrm{P}<0.0001$ ). The species richness estimator Jacknife 2

265 indicated that the completeness of macromycete species inventories was 56.26 to $60.86 \%$.

266 Shapiro-Wilk tests showed non-normal distributions of the data for soil and air humidity, tree

267 density and height, litter depth, and basal area. Thus, data were transformed for normality prior

268 to analyses. The regression tree analysis (residual mean deviance $=7.168$ ) indicated that the

269 variation of macromycete richness in $22.5 \%$ of the samples (plots) of the study area was related

270 to soil temperature $<17.63{ }^{\circ} \mathrm{C}$, while the number of species in $77.5 \%$ of the samples varied when

271 soil temperature was $>17.63{ }^{\circ} \mathrm{C}$. Within this $77.5 \%$ of the samples, species richness in $32.25 \%$

272 of them was influenced by soil temperatures $<19.58^{\circ} \mathrm{C}$, and in $65.27 \%$ of them it varied due to

273 soil temperature $>19.58^{\circ} \mathrm{C}$. Similarly, from this $65.27 \%$ of samples, species richness within

$27428.5 \%$ of them was influenced by air humidity below $54.47 \%$, whereas species richness in $71.5 \%$

275 of these samples varied with higher air humidity (Supplemental file S2).

276 Spearman correlation analyses indicated that all microclimatic variables were significantly

277 related to macromycete species richness within the study area. Both air and soil temperature

278 were negatively correlated with the number of species ( rho $=-0.56, \mathrm{P}=0.0001 ;$ rho $=-0.73, \mathrm{P}=$

$2797.8 \mathrm{e}-08$, respectively), whereas soil and air humidity were positively correlated ( $\mathrm{rho}=0.64, \mathrm{P}=$

$2807.1 \mathrm{e}-06 ;$ rho $=0.35, \mathrm{P}=0.02$, respectively). With regard to environmental variables, slope and

281 litter depth were positively correlated with the number of macrofungal species ( $\mathrm{rho}=0.31, \mathrm{P}=$

$2820.04 ;$ rho $=0.57, \mathrm{P}=9.32 \mathrm{e}-05$, respectively), while stoniness and soil cover showed a negative

283 correlation with richness ( $\mathrm{rho}=-0.43, \mathrm{P}=0.005 ;$ rho $=-0.37, \mathrm{P}=0.01$, respectively). Mean tree 
284 height was the only vegetation structure variable significantly correlated with macromycete

285 richness $(\mathrm{rho}=0.39, \mathrm{P}=0.01)($ Table 1$)$.

286 Macromycete species composition and distribution

287 The Chao-Jaccard similarity index showed a high turnover of species composition among study 288 sites. Species differed from 75.3 to $94.4 \%$; the highest similarity in species composition occurred 289 between Sites 3 and 4 (24.9\%), and the lowest was observed between Sites 1 and $3(5.6 \%)$ 290 (Supplemental file S3).

291 The CCA for microclimatic/environmental variables included air and soil humidity, air and soil 292 temperature, slope, aspect, soil and stoniness cover, litter depth, tree density, basal area, and 293 mean tree height, and it was performed for the 136 macromycete species recorded in the study 294 area. Axis 1 (eigenvalue $=0.88)$ and axis $2($ eigenvalue $=0.84)$ accounted for $10 \%$ and $9 \%$ of the 295 relationship between species distribution and explanatory variables, respectively (Monte Carlo 296 test, axis $1, \mathrm{~F}=1.4, \mathrm{P}=0.007$; axis $2, \mathrm{~F}=1.34, \mathrm{P}=0.024)$. CCA results showed a clear 297 separation between Site 1 and the other sites along axis 1, and several species were strongly 298 associated with this forest where air and soil humidity, slope, and mean tree height are the most 299 relevant variables. Site 2 is distinguished from Site 3 along axis 2, and the type of soil cover and 300 aspect were the variables most related to Site 2. Site 4 did not show a clear trend along axis 2 301 (Fig. 1)

302 The CCA for urbanization variables included the extent of crop and built areas, population 303 density, extent of introduced vegetation areas, street and road length, and 136 macromycete 304 species, but the model retained only three variables. Axis 1 (eigenvalue $=0.86$ ) and axis 2 305 (eigenvalue $=0.77$ ) accounted for $37 \%$ and $33 \%$ of the relationship between species distribution 306 and urbanization variables, respectively (Monte Carlo test, axis 1, F = 1.37, P = 0.001; axis 2, F $307=1.22, \mathrm{P}=0.003$ ). Site 1 was clearly separated from Sites 2,3 and 4 along axis 1 (Fig. 2). The

308 distribution of Site 2 was defined by the extent of crop area along axis 2. Sites 3 and 4 were not 309 distributed apart from each other and were strongly related to street/road length and extent of 310 built area (Fig. 2).

311 Functional diversity and functional value in macromycete communities 
312 The functional richness index (FRic) was the highest in Site 1 (10.66), followed by Site 2 (2.32),

313 Site $3(0.04)$ and Site 4 (0.01). The Spearman correlation coefficient indicated a positive relation 314 between species richness and FRic $(\rho=0.99, \mathrm{P}=5.29-7)$, and the patterns of these metrics were 315 similar throughout the study area (Kolmogorov-Smirnov, P > 0.05). Functional divergence

316 (FDig) showed its highest value in Site 4 (0.88), followed by Site 2 (0.77), Site 3 (0.76) and Site 317 1 (0.72). The Spearman correlation showed a negative relationship between species richness and 318 FDig $(\rho=-0.78, P=0.01)$. Functional evenness (FEve) did not show a significant trend along the 319 urbanization gradient. It was the highest in Site $2(0.63)$, followed by Site $1(0.61)$, Site $4(0.57)$ 320 and Site $3(0.54)$.

321 The AIC designated linear regression as the best fit model to evaluate the relationship between 322 the level of urbanization along the study area and the functional diversity values obtained for the 323 different trait groups (i.e., all the traits, morphological traits, and reproductive traits). FRic was 324 negatively related to urbanization level when calculated for both all the traits and morphological 325 traits $\left(\mathrm{r}^{2}=0.5, \mathrm{~F}=6.05, \mathrm{P}=0.49 ; \mathrm{r}^{2}=0.68, \mathrm{~F}=13, \mathrm{P}=0.01\right.$, respectively; Figs. 3A1, 4B1). 326 FDig for all the traits showed a positive relation with urbanization gradient $\left(\mathrm{r}^{2}=0.75, \mathrm{~F}=18.2, \mathrm{P}\right.$ $327=0.005$; Fig. 3A2). The rest of these results for FRic, FDig and FEve were not statistically 328 significant $(\mathrm{P}>0.05)$ (Fig. 3).

Linear regression was the best fit model designated by AIC to evaluate the relationship between the obtained FDig values and every urbanization variable, whereas linear and polynomial regressions were designed for FRic and FEve. FDig was the only index significantly related to urbanization variables; the analysis indicated a positive relation with the extent of built areas $\left(\mathrm{r}^{2}\right.$ $=0.85, \mathrm{~F}=36.63, \mathrm{P}=0.0008$; Fig. 4C1), street/road length $\left(\mathrm{r}^{2}=0.83, \mathrm{~F}=31.39, \mathrm{P}=0.001\right.$; Fig. 4C3), and population density $\left(\mathrm{r}^{2}=0.83, \mathrm{~F}=31.12, \mathrm{P}=0.001\right.$; Fig. 4C4). FRic and FEve were not significantly related to the urbanization variables $(\mathrm{P}>0.05)$ (Fig. 4A, B).

336 The recorded macromycetes included 75 species of ectomycorrhizas, 53 species of saprotrophs, and 6 species of parasites (Supplemental file S1). The functional value had an average of 8.74 and a range of 3.9-15.27, being markedly higher in the less urbanized site (Site 1) (Supplemental file S4). The ANOVA for the functional value indicated statistical differences between sites (DF $=3, \mathrm{~F}=16.53, \mathrm{P}<0.0001$ ), and the Tuke's HSD test revealed that Site 1 differs significantly from Sites 2, 3 and $4(\mathrm{P}<0.001)$, but Sites 2, 3 and 4 do not differ from each other $(\mathrm{P}>0.05)$. 
342 Polynomial regression was the best fit model designed by AIC to evaluate the relation between

343 functional value and macromycete species richness, and the analysis showed a positive relation $344\left(r^{2}=0.84, F=201.5, \mathrm{P}<0.0001 ;\right.$ Fig. 5).

\section{Discussion}

348

349

350

351

352

353

354

355

356

357

358

359

360

361

362

363

364

365

366

367

368

369

370

This is the first study to analyze the functional diversity of macromycete communities in an urban ecosystem in Mexico. Our results indicated a marked decline of macromycete richness, diversity and functional diversity with greater urbanization, and are consistent with studies conducted along urbanization gradients showing that species richness drastically decreased from the outskirts towards the urban core (Niemelä, 1999; Marzluff \& Ewing, 2001; McKinney, 2006). The decline of species richness with higher urbanization levels can be explained by the modification of biological interactions and habitat transformation. Macromycetes require interactions such as mycorrhizal-plant host and plant remains as substrates, thus changes in the structure of tree communities resulting from urbanization can influence macromycete richness by providing different habitats and affecting the quality and quantity of the available resources (Ferrer \& Gilbert, 2003; Richard et al., 2004; Brown, Bhagwat \& Watkinson, 2006; Newbound, McCarthy \& Lebel, 2010; Zhang et al., 2010). Besides, it is broadly known that habitat transformation can strongly affect microclimate conditions and diminish the number of fungi species (Lodge et al., 2004; Gómez-Hernández et al., 2012).

All the microclimatic variables analyzed in our study were related to species richness along the study area, but soil temperature and humidity showed the highest correlation (Table 1), and their variation was concordant with the variation of diversity, number of species and number of individuals among sites. In accordance with our results, other studies exploring macrofungal richness and abundance at the local scale in both tropical and temperate regions have shown them to be strongly related with environmental/microclimatic factors, mainly humidity and temperature (O’Dell, Ammirati \& Schreiner, 1999; Brown, Bhagwat \& Watkinson, 2006; Durall et al., 2006; Gómez-Hernández \& Williams-Linera, 2011; Caiafa et al., 2017). Even though humidity and temperature are key factors related with macromycete richness, distribution, and 
371 fruit body production worldwide, this relationship may diverge depending on regional

372 differences (Boddy et al. 2013). For example, in arctic-boreal regions, local increases of

373 temperature can foster fungi development and production, whereas the high-water content in

374 these regions can negatively affect macromycetes (Boddy et al. 2013; Blanchette et al. 2016). In

375 tropical regions, by contrast, studies that correspond with our results have shown that soil and air 376 temperature are negatively related to macromycete richness and abundance, whereas soil and air

377 humidity are positively related (Lodge \& Cantrell, 1995; Brown, Bhagwat \& Watkinson, 2006;

378 Caiafa et al., 2017; Ruiz-Almenara, Gándara \& Gómez-Hernández, 2019). In our study area, Site

3791 recorded the maximum diversity and number of macromycete species and individuals,

380 followed by Site 2, Site 3, and Site 4. Correspondingly, Site 1 presented the maximum soil

381 humidity and the lowest soil temperature (29.5\% and $16.9^{\circ} \mathrm{C}$, respectively), followed by Site 2

$382\left(8.4 \%\right.$ and $\left.19.4^{\circ} \mathrm{C}\right)$, Site $3\left(8.2 \%\right.$ and $\left.20.1^{\circ} \mathrm{C}\right)$, and Site $4\left(6.7 \%\right.$ and $\left.20.4^{\circ} \mathrm{C}\right)$. However, changes

383 in temperature and humidity affecting macrofungal communities along geographic or

384 environmental gradients have been suggested to be a function of the varying vegetation structure

385 (e.g., canopy openness, basal area, tree height, tree density) and environmental factors (e.g.,

386 slope, leaf litter depth, aspect, soil cover) (Brown, Bhagwat \& Watkinson, 2006; Cavender-Bares

387 et al., 2009; Zhang et al., 2010; Singha et al., 2017; Gómez-Hernández, Ramírez-Antonio \&

388 Gándara, 2019).

389 Our results showed that the variation of both species richness and distribution were related to 390 vegetation structure and environmental variables influencing microclimatic conditions (Table 1;

391 Fig. 1). Vegetation structure and organic matter produced by trees are among the main factors

392 affecting macromycete communities in the forests due to the heterogeneity of habitats, resources, 393 and resource quality they provide. Additionally, the water-holding capacity of dead organic 394 matter on the soil, such as leaf litter, promotes soil water content and avoids the increase of 395 temperature and loss of soil humidity, which are highly relevant for macrofungal growth (Ferris, 396 Peace \& Newton, 2000; Villeneuve, Grandtner \& Fortin,1989; Egli et al., 2010; Gómez-

397 Hernández \& Williams-Linera, 2011). Moreover, factors linked to the topography of a landscape 398 (e.g., soil surface unevenness, slope, aspect) can influence water drainage, evaporation rate, wind 399 exposure, and, in turn, soil and air temperature and humidity, affecting fruit body production, 400 and species richness and distribution (Nantel \& Neumann, 1992; Rubino \& McCarthy, 2003;

401 Gómez-Hernández et al., 2012; Caiafa et al., 2017). 
402 Similarly, urban factors appear to affect macrofungal communities along our study area (Fig. 2).

403 Macromycete species throughout the urbanization gradient are impacted mainly by the length of 404 streets/roads and the extent of built areas and, to a lesser extent, by the extent of crop areas.

405 Studies have suggested that impervious surfaces through urban areas can lead to poor water 406 absorption capacity by the soil, and drastically affect environmental temperature and humidity 407 (Newbound, McCarthy \& Lebel, 2010). In addition, temperature in urban landscapes can 408 increase owing to the heat island effect, which may be a consequence of the urban surface 409 capacity to absorb solar radiation, and the heterogeneous distribution of vegetation in urbanized 410 areas (Arnfield, 2003; Boone \& Fragkias 2012), thus resulting in a decrease in macromycete 411 richness and fruit body production, and changes in species composition (Ferris, Peace \& Newton, 412 2000; Rubino \& McCarthy, 2003; MacGregor-Fors, Avendaño-Reyes \& Bandala, 2015).

413 Within our studied area, functional richness (FRic) significantly decreased with urbanization 414 level (Fig. 3A1), and this corresponded with the observed trend in macromycete species richness. 415 The relationship between FRic and the number of species in biotic communities may be 416 explained, in part, because the number of species reflects the number of conserved traits through 417 the taxonomic lineages (Caiafa et al., 2017). This functional component of diversity gives 418 species richness a main role in the stability and functioning of ecosystems, influencing processes 419 such as productivity or resilience (Díaz et al., 2006; Mouchet et al., 2010; Sol et al., 2020). Since 420 FRic is a measure of richness indicating the amount of niche space occupied by the species in a 421 community, low values of FRic in urbanized sites of our study area suggest that fewer available 422 resources within these communities are being used. This may be explained because the loss of 423 macromycete species caused by urbanization can lead to communities with a narrow range of 424 functional traits (which are directly linked to taxonomic differences), and assemblages of species 425 426 unable to take advantage of potentially available resources (Mason et al., 2005; Caiafa et al., 2017). FRic also decreased throughout the urbanization gradient in our study area when calculated with morphological traits (Fig. 3B1).

428 Our findings showed that functional divergence (FDig) significantly increased with urbanization 429 level when analyzed using all the traits (Fig. 3A2) and was positively related to urbanization variables (Figs. 4C1, 3, 4). FDig measures the degree of niche differentiation based on the 431 distribution of the total abundance in the niche space supported by the species with the most 
432 extreme functional traits (Mason et al., 2005; Mouillot et al., 2013). The increasing FDig with

433 urbanization level indicates a high degree of niche differentiation among macromycete species

434 within communities in urbanized areas. This means that species with higher abundance are

435 functionally dissimilar, thus they occur at the extremes of the niche space (Mason et al., 2005;

436 Mouchet et al., 2010). Since most of the resources are being used by species with the most

437 extreme functional traits, the results indicated that the scarcely occupied niche space and under-

438 utilized resources in urban communities, suggested by FRic, are close to the center of the

439 functional trait range (Villéger, Mason \& Mouillot, 2008). Functional evenness (FEve) did not

440 show significant variation along the urbanization gradient (Figs. 3A3, B3, C3). FEve measures

441 the regularity in the distribution of species abundance along the functional space for a given

442 community, and our results suggest that in spite of urbanization having caused a reduction in the

443 niche space occupied by macromycete species (indicated by FRic) and a high niche

444 differentiation (indicated by FDig), there is not much variation in the distribution of abundances

445 within the occupied parts of the niche space (Mason et al., 2005; Mouillot et al., 2013).

446 The morphology-related traits that we selected to calculate the functional diversity indexes are

447 "response traits" (i.e., they can affect organism's performance under different environmental

448 conditions), and are associated to macromycete dispersion, establishment, uptake of new

449 resources, and reproduction. The fruit body texture relates to timing of spore production due to

450 its link to fruit body longevity, which can vary from few days to several months; hymenium type

451 is involved in how spores are released; pileus diameter is related to hymenial area and hence to

452 spore production; and spore size and shape are related to dispersal fitness, dormancy, and

453 germinability (Moore et al., 2008; Norden et al., 2013; Bässler et al., 2015). The functional

454 diversity indexes indicated that some sections of the niche space are unoccupied and available

455 resources underutilized in the most urbanized sites, suggesting that the

456 microclimatic/environmental conditions derived from urbanization are reducing the morphology-

457 related trait diversity, and hence macromycete species performance. Since macromycetes play a

458 main role in terrestrial ecosystems, their limited capacity to disperse, establish and reproduce in

459 the niche space, and use available resources can affect plants access to nutrients, rates of organic

460 matter decomposition, and regulation of organismal populations (Deacon, 2006, Egli, 2011,

461 Zanne et al., 2020), which could affect the ecosystem functioning and productivity (Petchey,

462 2003; McKinney, 2006). 
463 Studies have found that changes in the structure of tree communities can impair macromycete

464 functional guilds mainly due to the physicochemical attributes of the soil are altered as well as

465 the quality and quantity of available organic matter (Dighton \& Mason, 1985; Fernández-Toirán, 466 Ágreda \& Olano, 2006; Gómez-Hernández, Ramírez-Antonio \& Gándara, 2019). The functional

467 value metric showed that Site 1 (National Park) differs widely from the other sites regarding 468 macromycete functional attributes, whereas Sites 2, 3 (rural areas) and 4 (city) do not differ from 469 each other. Since this metric characterizes functional guilds and their prevalence in a site (Avis et 470 al., 2016), the results suggest that the impact of urbanization on the ecological function of 471 macromycetes can become equally drastic in both the urban core and the rural hinterlands.

472 Despite most studies evaluating patterns of macromycete diversity report an increasing diversity 473 from disturbed to conserved areas, evidence indicates that this trend can differ when functional 474 guilds are evaluated (Fernández-Toirán, Ágreda \& Olano, 2006; Vásquez et al., 2011), which 475 means that species richness and functional guild approaches can provide different information. 476 Our results showed a positive correlation between functional value and species richness, and a 477 high turnover of species composition among sites, making this information of interest to infer 478 about the variation of the ecological functioning of macromycetes along the study area.

479 However, it has been suggested that functional value is a more informative metric than species 480 richness when assessing fungal ecological function, and offers a better predictive framework 481 than species composition for understanding fungal function across systems with few species in 482 common, which can be explained because species diversity and distribution at local scale are 483 determined mainly by niche differences and competition (Kraft \& Ackerly, 2010; Talbot et al. 484 2014; Avis et al., 2016)

485 The present study included only one season of data, which could be a limitation. However, 486 sampling was carried out on several dates considering fungal phenology and recorded more than $48750 \%$ of the species. Since the sampling procedure was the same in the four study sites, the 488 obtained data can be compared between sites and get suitable results to understand how diversity 489 varies along the studied area. Owing to the lack of appropriate lab equipment and experience 490 analyzing atmospheric and soil pollutants, our study did not evaluate their effect on macromycete 491 communities. However, evidence indicates they are urbanization factors that negatively impact 492 fungal communities, altering their performance within urban environments (Grimm et al., 2008; 
493 Newbound, McCarthy \& Lebel, 2010). This evidence should prompt future macromycete studies 494 to include this kind of urban variable.

495

496

497

498

499

500

501

502

503

504

505

506

507

508

509

510

511

512

513

514 2016).

\section{Acknowledgements}

517 We thank the Commissariat of Communal Assets in San Pablo Etla, San Pedro Ixtlahuaca, and

518 Santo Domingo Tomaltepec, and the Natural Resources and Sustainable Development

519 Directorate in Oaxaca City for granting permits to carry out the project in these localities; Dra.

520 Sandra Smith Aguilar for helpful suggestions and comments on earlier versions of this

Peer] reviewing PDF | (2021:03:59452:2:0:NEW 22 Aug 2021) 
521 manuscript; Dr. Peter Avis and one anonymous reviewer for important and useful comments that

522 greatly improved the manuscript.

523

524

525 References

526 Aguilar-Trigueros CA, Hempel S, Powell JR, Anderson IC, Antonovics J, Bergmann J,

527 Cavagnaro TR, Chen B, Hart MM, Klironomos J. 2015. Branching out: towards a trait-based

528 understanding of fungal ecology. Fungal Biology Reviews 29:34-41 DOI

529 10.1016/j.fbr.2015.03.001

530 Akaike H. 1973. Information theory and an extension of the maximum likelihood principle. In:

531 Pertaran B.N, Csaaki F, eds. International Symposium on Information Theory, 2nd ed. Budapest:

532 Acadeemiai Kiadi, pp. 267-281.

533 Avis PG, Gaswick WC, Tonkovich GS, Leacock PR. 2016. Monitoring fungi in ecological

534 restorations of coastal Indiana, U.S.A. Restoration Ecology 25: 92-100 DOI 10.1111/rec.12397

535 Arnfield AJ. 2003. Two decades of urban climate research: A review of turbulence, exchanges of 536 energy and water, and the urban heat island. International Journal of Climatology 23:1-26 DOI

$537 \quad 10.1002 /$ joc. 859

538 Barrico L, Azul AM, Morais MC, Pereira-Coutinho A, Freitas H, Castro P. 2012. Biodiversity in 539 urban ecosystems: Plants and macromycetes as indicators for conservation planning in the city of 540 Coimbra (Portugal). Landscape and Urban Planning 106:88-102 DOI

541 10.1016/j.landurbplan.2012.02.011.

542 Bässler C, Heilmann-Clausen J, Karasch P, Brandl R, Halbwachs H., 2015. Ectomycorrhizal

543 fungi have larger fruit bodies than saprotrophic fungi. Fungal Ecology 17:205-212 DOI

544 10.1016/j.funeco.2014.06.005 
545 Blanchette RA, Held BW, Hellmann L, Millman L, Büntgen U. 2016. Arctic driftwood reveals

546 unexpectedly rich fungal diversity. Fungal Ecology 23: 58-65 DOI

547 10.1016/j.funeco.2016.06.001

548 Boddy L, Büntgen U, Egli S, Gange AC, Heegaard E, Kirk PM, Mohammad A, Kauserud H.

549 2013.Climate variation effects on fungal fruiting. Fungal Ecology 10: 20-33 DOI

$55010.1016 /$ j.funeco.2013.10.006.

551 Boone CG, Fragkias M. 2012. Urbanization and sustainability: linking urban ecology,

552 environmental justice and global environmental change. Springer.

553 Branco S, Ree RH. 2010. Serpentine soils do not limit mycorrhizal fungal diversity. PLOS ONE

554 5: e11757. DOI 10.1371/journal.pone.0011757

555 Breitenbach J, Kränzlin F. 1984. Fungi of Switzerland. Vol. 1: Ascomycetes. Verlag Mykologia, 556 Luzern, Switzerland.

557 Breitenbach J, Kränzlin F. 1986. Fungi of Switzerland. Vol. 2: Non-gilled fungi. Verlag 558 Mykologia, Luzern, Switzerland.

559 Breitenbach J, Kränzlin F. 1991. Fungi of Switzerland. Vol. 3: Boletes and agarics. Part 1:

560 Strobilomycetaceae, Boletaceae, Paxillaceae, Gomphidiaceae, Hygrophoraceae,

561 Tricholomataceae, Polyporaceae (lamellate). Verlag Mykologia, Luzern, Switzerland.

562 Brown N, Bhagwat S, Watkinson S. 2006. Macrofungal diversity in fragmented and disturbed

563 forests of the Western Ghats of India. Journal of Applied Ecology 43:11-17 DOI 10.1111/j.1365-

564 2664.2005.01107.x.

565 Caiafa MV, Gómez-Hernández M, Williams-Linera G, Ramírez-Cruz V. 2017. Functional

566 diversity of macromycete communities along an environmental gradient in a Mexican seasonally

567 dry tropical forest. Fungal Ecology 28:66-75 DOI 10.1016/j.funeco.2017.04.005.

568 Cadotte MW, Cavender-Bares J, Tilman D, Oakley TH. 2009. Using phylogenetic, functional

569 and trait diversity to understand patterns of plant community productivity. Plos One 4: e5695

570 DOI 10.1371/journal.pone.0005695 
571 Cavender-Bares J, Izzo A, Robinson R, Lovelock CE. 2009. Changes in ectomycorrhizal

572 community structure on two containerized oak hosts across an experimental hydrologic gradient.

573 Mycorrhiza 19:133-142 DOI 10.1007/s00572-008-0220-3

574 Chao A, Chazdon RL, Colwell RK, Shen T. 2005. A new statistical approach for assessing

575 similarity of species composition with incidence and abundance data. Ecology Letters 8: 148-

576 159. DOI 10.1111/j.1461-0248.2004.00707.x

577 Colwell RK. 2013. EstimateS, Version 9.1: statistical estimation of species richness and shared 578 species from samples. Available at http://viceroy.eeb.uconn.edu/estimates/

579 CONAPO. 2014. Dinámica demográfica 1990-2010 y proyecciones de población 2010-2030.

580 Oaxaca. Primera edición, p. 42.

581 Conway TM, Hackworth J. 2007. Urban pattern and land cover variation in the Greater Toronto 582 Area. Canadian Geographer 51:43-57 DOI 10.1111/j.1541-0064.2007.00164.x

583 Cousins JR, Hope D, Gries C, Stutz JC. 2003. Preliminary assessment of arbuscular mycorrhizal 584 fungal diversity and community structure in an urban ecosystem. Mycorrhiza 13:319-326 DOI $58510.1007 / \mathrm{s} 00572-003-0239-4$

586 Crowther TW, Maynard DS, Crowther TR, Peccia J, Smith JR, Bradford MA. 2014. Untangling 587 the fungal niche: the trait-based approach. Frontiers in Microbiology 5: 1-12 DOI 588 10.3389/fmicb.2014.00579

589 Deacon J. 2006. Fungal biology. Fourth Edition. Oxford: Blackwell Malden Publishing.

590 De'ath G, Fabricius KE. 2000. Classification and regression trees: a powerful yet simple 591 technique for ecological data analysis. Ecology 81: 3178319 DOI 10.1890/0012-

592 9658(2000)081[3178:CARTAP]2.0.CO;2

593 Diaz S, Cabido M. 2001. Vive la difference: plant functional diversity matters to ecosystem 594 processes. Trends in Ecology and Evolution 16:646-655 DOI 10.1016/S0169-5347(01)02283-2

595 Diaz S, Fargione J, Chapin FS, Tilman D. 2006: Biodiversity loss threatens human well-being. 596 PLoS Biol 4:1300-1305 DOI 10.1371/journal.pbio.0040277 
597 Dighton J, Mason PA. 1985. Mycorrhizal dynamics during forest tree development. In: Moore D, 598 Casselton L, Wood DA, Frankland JC, eds. Developmental Biology of Higher Fungi. London: 599 Cambridge University Press, 117-139.

600 Dighton J. 2003. Fungi in ecosystem processes. Marcel Dekker, New York. DOI $601 \quad 10.1201 / 9781315371528$

602 Durall DM, Gamiet S, Simard SW, Kudrna L, Sakakibara SM. 2006. Effects of clearcut logging 603 and tree species composition on the diversity and community composition of epigeous fruit 604 bodies formed by ectomycorrhizal fungi. Canadian Journal of Botany 84:966-980 DOI $60510.1139 / \mathrm{b} 06-045$.

606 Egli S, Ayer F, Peter M, Eilmann B, Rigling A. 2010. Is forest mushroom productivity driven by 607 tree growth? Results from a thinning experiment. Annals of Forest Science 67:509-509 DOI $60810.1051 /$ forest/2010011.

609 Egli S. 2011. Mycorrhizal mushroom diversity and productivity-an indicator of forest healt? 610 Annals of Forest Science 68:81-88 DOI 10.1007/s13595-010-0009-3.

611 ESRI Inc., 2016. ArcGIS (Version 10.4).

612 Ferrer A, Gilbert GS. 2003. Effect of tree host species on fungal community composition in a 613 tropical rainforest in Panama. Diversity and Distributions 9:455-468 DOI: 10.1046/j.1472614 4642.2003.00039.x

615 Ferris R, Peace AJ, Newton AC. 2000. Macrofungal communities of lowland Scots pine (Pinus 616 sylvestris L.) and Norway spruce (Picea abies (L.) Karsten.) plantations in England: relationships 617 with site factors and stand structure. Forest Ecology and Management 131:255-267 DOI 618 10.1016/S0378-1127(99)00218-2.

619 Flores-Villela O, Gerez P. 1994. Biodiversidad y conservación en México: vertebrados, 620 vegetación y uso del suelo. Second Edition. Mexico City: Universidad Nacional Autónoma de 621 México. 
622 Flynn D, Gogol-Prokurat M, Nogeire T, Molinari N, Richers BT, Lin BB, Simpson N, Mayfield

623 MM, Declerck F. 2009. Loss of functional diversity under land use intensification across

624 multiple taxa. Ecology Letters 12: 22-33 DOI 10.1111/j.1461-0248.2008.01255.x

625 Gómez-Hernández M, Williams-Linera G. 2011. Diversity of macromycetes determined by tree

626 species, vegetation structure, and microenvironment in tropical cloud forests in Veracruz,

627 Mexico. Botany 89:203-216 DOI 10.1139/B11-007.

628 Gómez-Hernández M, Williams-Linera G, Guevara R, Lodge DJ. 2012. Patterns of macromycete

629 community assemblage along an elevation gradient: options for fungal gradient and

630 metacommunity analyse. Biodiversity and Conservation 21:2247-2268 DOI 10.1007/s10531-

631 011-0180-3.

632 Gómez-Hernández M, Ramírez-Antonio KG, Gándara E. 2019. Ectomycorrhizal and wood-

633 decay macromycete communities along development stages of managed Pinus patula stands in

634 Southwest Mexico. Fungal Ecology 39:109-116 DOI 10.1016/j.funeco.2018.12.007

635 Grimm NB, Faeth SH, Golubiewski NE, Readman CL, Wu J, Bai X, Briggs JM. 2008. Global

636 change and the ecology of cities. Science 319:756-760

637 Gross G. 1972. Kernzahl und sporenvolumen bei einigen Hymenogasterarten. Zeit Pilzk, pp.

$638 \quad 109-158$.

639 Guzmán G. 1977. Identificación de los hongos: comestibles, venenosos y alucinantes. Limusa.

640 México, D.F.

641 Hall IR, Yun W, Amicucci A. 2003. Cultivation of edible ectomycorrhizal mushrooms. Trends in 642 Biotechnology 21:433-438 DOI 10.1016/S0167-7799(03)00204-X.

643 Hansen EM, Stone JK. 2005. Interactions of pathogens with plant communities. In: Dighton J, 644 Oudemans P, White J, eds. The Fungal Community. New York: Marcel Dekker, 461.

645 Hooper D, Buchmann N, Degrange V, Diaz S, Gessner M, Grime P, Hulot F, Mermillod-Blondin

646 F, Peer L, Roy J, Symstad A, Solan M, Spehn E. 2002. Species diversity, functional diversity and 647 ecosystem functioning. In: Loreau M, Naeem S, Inchausti P, eds. Biodiversity and ecosystems 648 functioning: a current synthesis. Oxford: Oxford University Press , 195-208. 
649 INEGI. 2013. Diccionario de Datos Topográficos escala 1:50 000 (versión 2). Available at 650 http://www.inegi.org.mx (accessed August 2019)

651 INEGI. 2015a. Principales resultados de la Encuesta Intercensal. Oaxaca. pp 92

652 INEGI. 2015b. Encuesta intercensal. Available at https://www.inegi.org.mx/ (accessed July 653 2019)

654 INEGI. 2017. Estado de Oaxaca. Generalidades. Available at http://www.oaxaca.gob.mx 655 (accessed August 2019)

656 Jost L. 2006. Entropy and diversity. Oikos 113:363-375 DOI 10.1111/j.2006.0030-1299.14714.x

657 Jost L. 2007. Partitioning diversity into independent alpha and beta components. Ecology 658 88:2427-2439 DOI 10.1890/06-1736.1

659 Koide RT, Fernandez C, Malcolm G. 2014. Determining place and process: functional traits of 660 ectomycorrhizal fungi that affect both community structure and ecosystem function. New 661 Phytologist 201: 433-439 DOI 10.1111/nph.12538

662 Kraft NJB, Ackerly D. 2010. Functional trait and phylogenetic tests of community assembly 663 across spatial scales in an Amazonian forest. Ecological Monographs 80:401-422 DOI $664 \quad 10.1890 / 09-1672.1$

665 Largent DL. 1986. How to identify mushrooms to genus I: Macroscopic features. Mad River 666 Press: Eureka, CA. 166 pp.

667 Largent DL, Thiers HD. 1977. How to identify mushrooms to genus II: Field identification of 668 genera. Mad River Press: Eureka, CA. 32 pp.

669 Largent DL, Johnson D, Watling R. 1977. How to identify mushrooms to genus III: Microscopic 670 features. Mad River Press: Eureka, CA. 148 pp.

671 Largent DL, Baroni T. 1988. How to identify mushrooms to genus VI: Modern genera. Mad 672 River Press: Eureka, CA. 277 pp.

673 Legendre P, Legendre L. 2012. Numerical Ecology. 3rd English ed. Elsevier. 
674 Lodge DJ, Cantrell S. 1995. Fungal communities in wet tropical forests: variation in time and 675 space. Canadian Journal of Botany 73:1391-1398 DOI 10.1139/b95-402

676 Lodge DJ, Ammirati JF, O’Dell TE, Mueller GM. 2004. Collecting and describing macrofungi. 677 In: Mueller GM, Bills GF, Foster MS, eds. Biodiversity of Fungi: Inventory and Monitoring 678 Methods. Amsterdam: Elsevier Inc., 128-168.

679 Lonsdale D, Pautasso M, Holdenrieder O. 2008. Wood-decaying fungi in the forest: conservation 680 needs and management options. European Journal of Forest Research 127:1-22 DOI 681 10.1007/s10342-007-0182-6

682 MacGregor-Fors I, Ortega-Álvarez R. 2013. Ecología urbana: Experiencias en América Latina. 683 Instituto de Ecología, A. C.

684 MacGregor-Fors I, Avendaño-Reyes S, Bandala VM, Chacón-Zapata S, Díaz-Toribio M, 685 González-García F, Lorea-Hernández F, Martínez-Gómez J, Montes de Oca E, Montoya L, 686 Pineda E, Ramírez-Restrepo L, Rivera-García E, Utrera-Barrillas E, Escobar F. 2015. Multi687 taxonomic diversity patterns in a neotropical green city: a rapid biological assessment. Urban 688 Ecosyst 18:633-647 DOI 10.1007/s11252-014-0410-z

689 Marsaglia G, Tsang W, Wang J. 2003. Evaluating Kolmogorov's Distribution. Journal of 690 Statistical Software 8: 1-4 DOI 10.18637/jss.v008.i18

691 Marzluff JM, Ewing K. 2001. Restoration of fragmented landscapes for the conservation of 692 birds: a general framework and specific recommendations for urbanizing landscapes. Restoration 693 Ecology 9:280-292 DOI 10.1007/978-0-387-73412-5_48

694 Mason NWH, Mouillot D, Lee WG, Wilson J.B. 2005. Functional richness, functional evenness 695 and functional divergence: the primary components of functional diversity. Oikos 111:112-118 696 DOI 10.1111/j.0030-1299.2005.13886.x

697 McDonnell MJ, Pickett STA. 1990. Ecosystem structure and function along urban-rural 698 gradients: an unexploited opportunity for ecology. Ecology 71:1232-1237 DOI 10.2307/1938259 
699 McDonnell MJ, Hahs AK. 2008. The use of gradient analysis studies in advancing our 700 understanding of the ecology of urbanizing landscapes: current status and future directions. 701 Landscape Ecology 23:1143-1155 DOI 10.1007/s10980-008-9253-4

702 McGill BJ, Enquist BJ, Weiher E, Westoby M. 2006. Rebuilding community ecology from 703 functional traits. Trends in Ecology and Evolution 21:178-185 DOI 10.1016/j.tree.2006.02.002

704 McKinney ML. 2006. Urbanization as a major cause of biotic homogenization. Biological 705 Conservation 127:247-260 DOI 10.1016/j.biocon.2005.09.005

706 McPhearson T, Pickett STA, Grimm NB, Niemelä J, Alberti M, Elmqvist T, Weber Ch, Haase 707 D, Breuste J, Qureshi S.2016. Advancing urban ecology toward a science of cities BioScience 708 66:198-212 DOI 10.1093/biosci/biw002

709 Moore D, Gange AC, Gange EG, Boddy L. 2008. Fruit bodies: their production and development 710 in relation to environment. In: Boddy L, Frankland JC, van West P, eds. Ecology of Saprotrophic 711 Basidiomycetes. UK: Elsevier, 9e103.

712 Mouchet MA, Villeger S, Mason NWH, Mouillot D. 2010. Functional diversity measures: an 713 overview of their redundancy and their ability to discriminate community assembly rules.

714 Functional Ecology 24:867-876 DOI 10.1111/j.1365-2435.2010.01695.x

715 Mouillot, D., Graham, N.A.J., Villeger, S., Mason, N.W.H., Bellwood, D.R., 2013. A functional 716 approach reveals community responses to disturbances. Trends in Ecology and Evolution 717 28:167-177 DOI 10.1016/j.tree.2012.10.004

718 Mueller GM, Bills GF. 2004. Introduction. In: Mueller GM, Foster MS, eds. Biodiversity of 719 Fungi: Inventory and Monitoring Methods. San Diego: Elsevier Academic Press, 1-4.

720 Nantel P, Neumann P. 1992. Ecology of ectomycorrhizal-basidiomycete communities on a local 721 vegetation gradient. Ecology 73:99 DOI 10.1210/er.2008-0024.

722 Newbound M, Mccarthy MA, Lebel T. 2010. Fungi and the urban environment: A review. 723 Landscape and Urban Planning 96: 138-145 DOI: 10.1016/j.landurbplan.2010.04.005 
724 Niemelä J. 1999. Is there a need for a theory of urban ecology?. Urban Ecosystems 3:57-65 DOI

725 10.1023/A:1009595932440

726 Norden J, Penttilä R, Siitonen J, Tomppo E, Ovaskainen O. 2013. Specialist species of wood-

727 inhabiting fungi struggle while generalists thrive in fragmented boreal forests. Journal of

728 Ecology 101:701-712 DOI 10.1111/1365-2745.12085

729 O’Dell TE, Ammirati JF, Schreiner EG. 1999. Species richness and abundance of

730 ectomycorrhizal basidiomycete sporocarps on a moisture gradient in the Tsuga heterophylla

731 zone. Canadian Journal of Botany 77: 1699-1711 DOI 10.1139/cjb-77-12-1699

732 Ortega-Álvarez R, Rodríguez-Correa HA, MacGregor-Fors I. 2011. Trees and the city: diversity 733 and composition along a neotropical gradient of urbanization. International Journal of Ecology 734 art. no. 704084 DOI: $10.1155 / 2011 / 704084$

735 Pegler DN. 1986. Agaric flora of Sri Lanka. Kew Bulletin Additional Series XII, Her Majesty's 736 St. Off., Londres. 519 pp.

737 Petchey OL. 2003. Integrating methods that investigate how complementarity influences

738 ecosystem functioning. Oikos 101:323-330 DOI 10.1034/j.1600-0706.2003.11828.x

739 Pringle A, Vellinga E, Peay K. 2015. The shape of fungal ecology: does spore morphology give 740 clues to a species' niche? Fungal Ecology 17: 213-216 DOI 10.1016/j.funeco.2015.04.005

741 R Development Core Team. 2017. R: a Language and Environment for Statistical Computing, 742 3.4.2. Vienna: The R Foundation for Statistical Computing. Available at https://www.R743 project.org/.

744 Richard F, Moreau PA, Selosse MA, Gardes M. 2004. Diversity and fruiting patterns of 745 ectomycorrhizal and saprobic fungi in an old-growth Mediterranean forest dominated by 746 Quercus ilex L. Canadian Journal of Botany 82:1711-1729 DOI 10.1139/b04-128.

747 Rubino DL, McCarthy BC. 2003. Composition and ecology of macrofungal and myxomycete 748 communities on oak woody debris in a mixed-oak forest of Ohio. Canadian Journal of Forest 749 Research 33:2151-2163 DOI 10.1139/x03-137. 
750 Ruiz-Almenara C, Gándara E, Gómez-Hernández M. 2019. Comparison of diversity and

751 composition of macrofungal species between intensive mushroom harvesting and non-harvesting

752 areas in Oaxaca, Mexico. PeerJ 7:e8325 DOI 10.7717/peerj.8325

753 Shapiro SS, Wilk MB. 1965. An Analysis of Variance Test for Normality (Complete Samples).

754 Biometrika 52 591-611 DOI 10.2307/2333709

755 Singha K, Banerjee A, Pati BR, Das Mohapatra PK 2017 - Eco-diversity, productivity and

756 distribution frequency of mushrooms in Gurguripal Eco-forest, Paschim Medinipur, West

757 Bengal, India. Current Research in Environmental \& Applied Mycology 7:8-18 DOI

$75810.5943 /$ cream $/ 7 / 1 / 2$

759 Sol D, Trisos Ch, Múrria C, Jeliazkov A, González-Lagos C, Pigot AL, Ricotta C, Swan ChM,

760 Talbot JM, Bruns TD, Taylor JW, Smith DP, Branco S, Glassman SI, Erlandson S, Vilgays R,

761 Liao H, Smith ME, Peay KG. 2014. Endemism and functional convergence across the North

762 American soil mycobiome. Proceedings of the National Academy of Sciences 111: 6341-6346

763 DOI 10.1073/pnas.1402584111

764 Tobias JA, Pavoine S. 2020. The worldwide impact of urbanisation on avian functional

765 diversity. Ecology Letters 23:962-972 DOI 10.1111/ele.13495

766 Tsianou MA, Kallimanis AS. 2016. Different species traits produce diverse spatial functional

767 diversity patterns of amphibians. Biodiversity and Conservation 25:117-132 DOI

768 10.1007/s10531-015-1038-x

769 United Nations, Department of Economic and Social Affairs, Population Division. 2014. World 770 Urbanization Prospects: The 2014 Revision Highlights. UN.

771 United Nations, Department of Economic and Social Affairs, Population Division. 2018. The

772 World's Cities in 2018—Data Booklet (ST/ESA/ SER.A/417).

773 Vásquez P, Fraile R, Hernández-Rodríguez M, Oria-de-Rueda JA, Martín-Pinto P. 2011. Fungal

774 community succession following wildfire in a Mediterranean vegetation type dominated by

775 Pinus pinaster in Northwest Spain. Forest Ecology and Management 262: 655e662 DOI

776 10.1016/j.foreco.2011.04.036. 
777 Villeger S, Mason NWH, Mouillot D. 2008. New multidimensional functional diversity indices

778 for a multifaceted framework in functional ecology. Ecology 89: 2290-2301 DOI 10.1890/07-

$779 \quad 1206.1$

780 Villeneuve N, Grandtner MM, Fortin JA. 1989. Frequency and diversity of ectomycorrhizal and

781 saprophytic macrofungi in the Laurentide Mountains of Quebec. Canadian Journal of Botany

782 67:2616-2629 DOI 10.1139/b89-338.

783 Worldometers.info. 2020. Available at https://www.worldometers.info/ (accessed early 2020)

784 Zanne AE, Abarenkov K, Afkhami ME, Aguilar-Trigueros CA, Bates S, Bhatnagar JM, Busby

785 PE, Christian N, Cornwell WK, Crowther TW, Flores-Moreno H, Floudas D, Gazis R, Hibbett

786 D, Kennedy P, Lindner DL, Maynard DS, Milo AM, Nilsson RH, Powell J, Schildhauer M,

787 Schilling J, Treseder KK. 2020. Fungal functional ecology: bringing a trait-based approach to

788 plant-associated fungi. Biological Reviews 95: 409-433 DOI $\underline{10.1111 / \text { brv.12570 }}$

789 Zhang Y, Zhou DQ, Zhao Q, Zhou TX, Hyde KD. 2010. Diversity and ecological distribution of 790 macrofungi in the Laojun Mountain region, southwestern China. Biodiversity and Conservation 791 19:3545-3563 DOI 10.1007/s10531-010-9915-9. 
Figure 1

CCA for the macromycete species recorded in the four study sites.

Vectors are microclimatic, environmental, and vegetation structure variables: air humidity (airH), soil humidity (soilH), air temperature (airT), soil temperature (soilT), slope, aspect, stoniness cover (StoneC), mean tree height (treeH), tree density (treed), and basal area (BA).

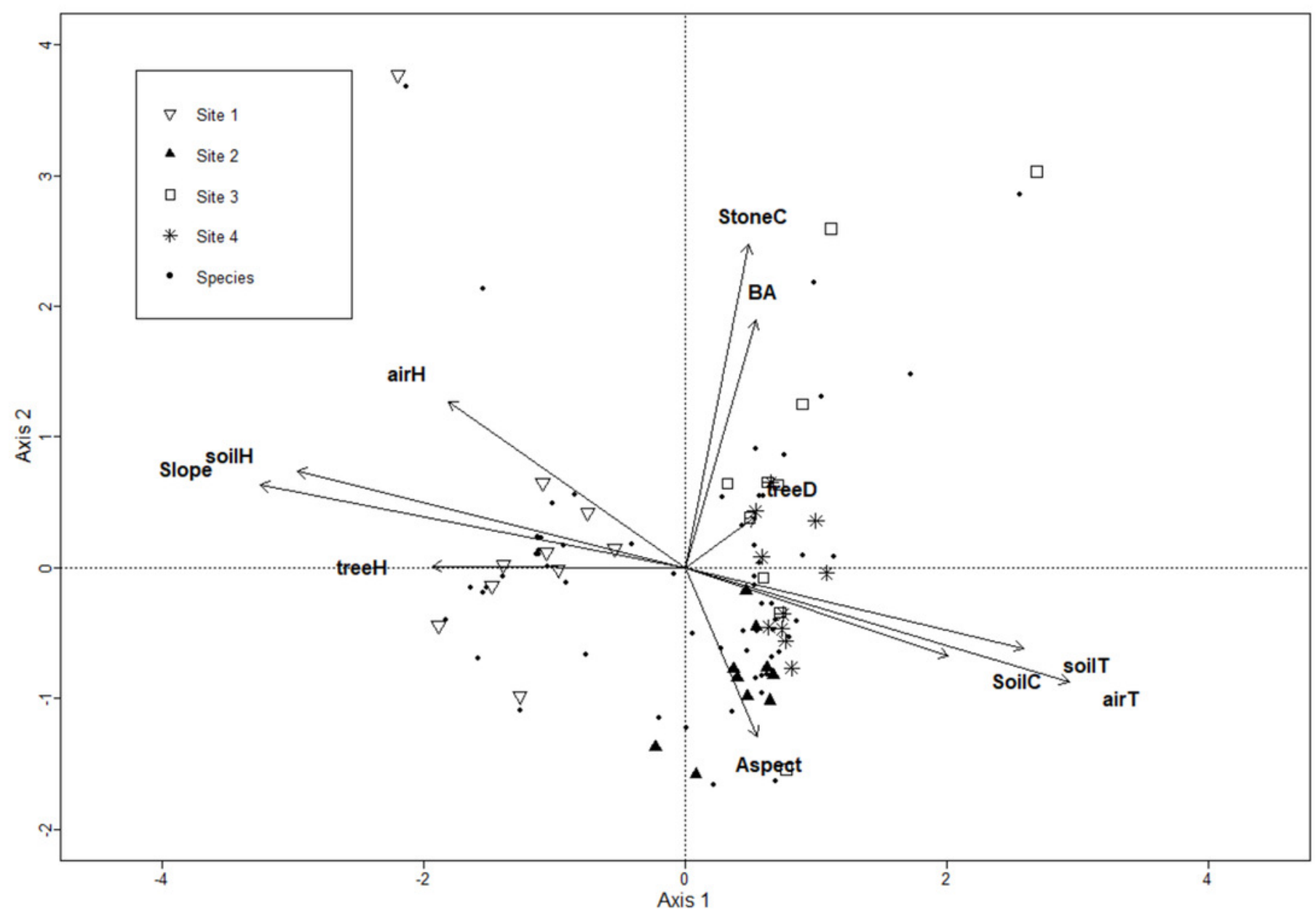


Figure 2

CCA for macromycete species recorded in the four study sites.

Vectors correspond to urban variables: extent of crop areas (Crop), extent of built areas (Built), and length of roads and streets (stLength).

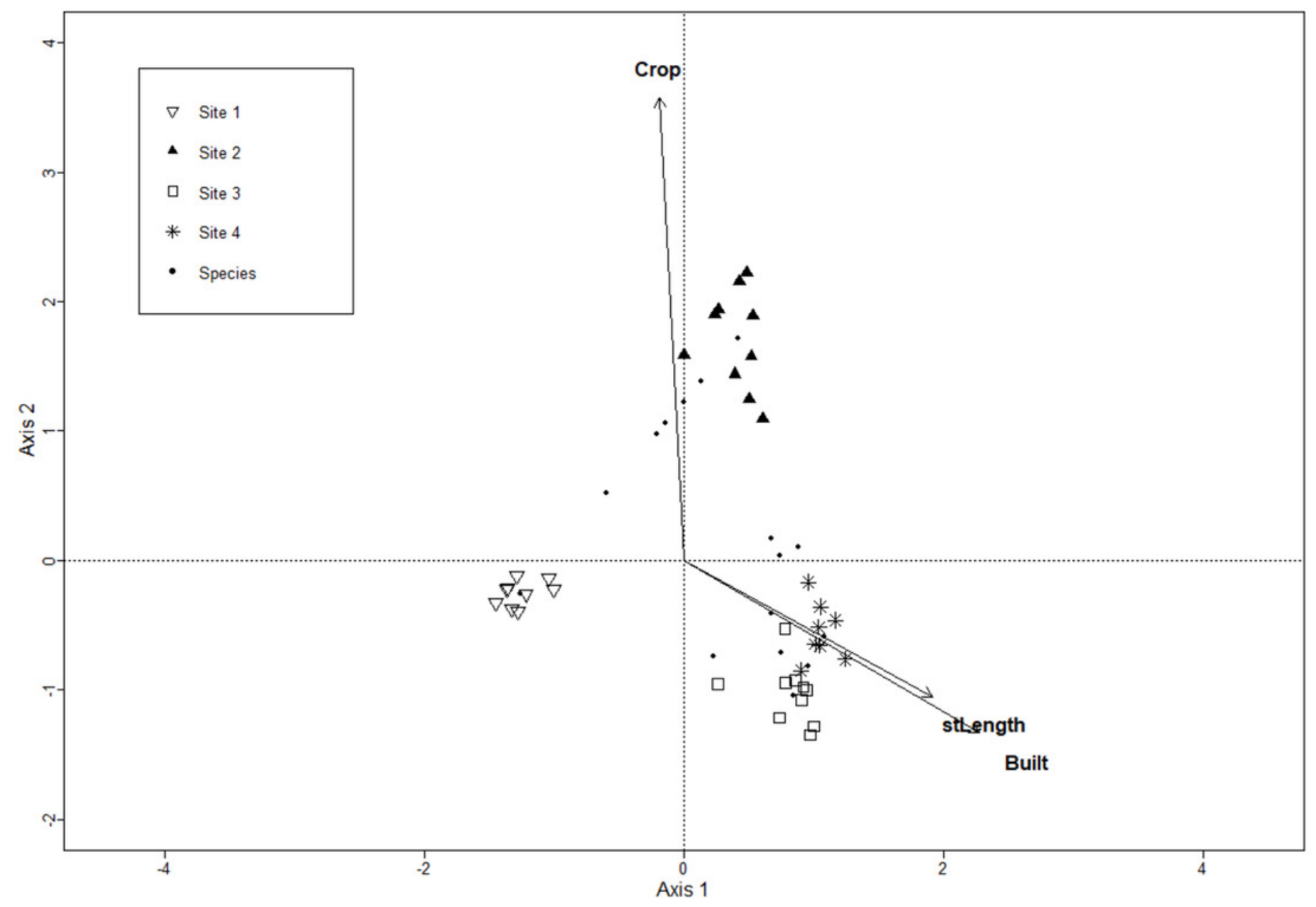


Figure 3

Linear regression analysis for functional richness (FRic), functional divergence (FDiv), and functional evenness (FEve) along the urbanization gradient.

Analyses were performed using three trait groups: all traits, morphological traits, and reproductive traits.
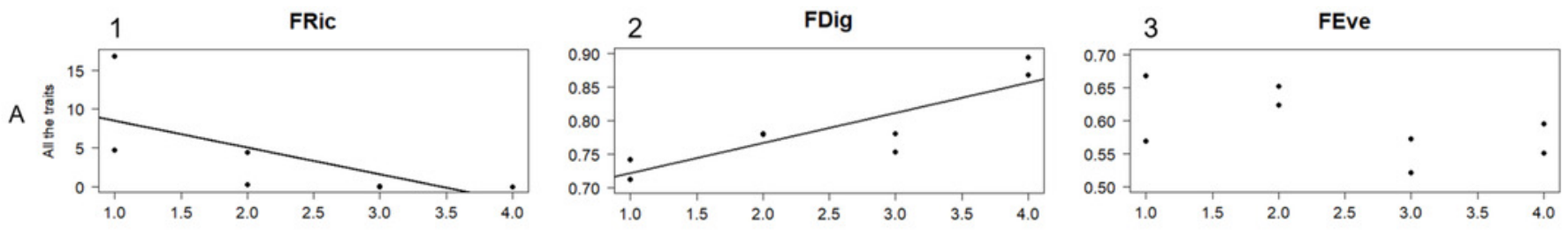

$\mathrm{B}$
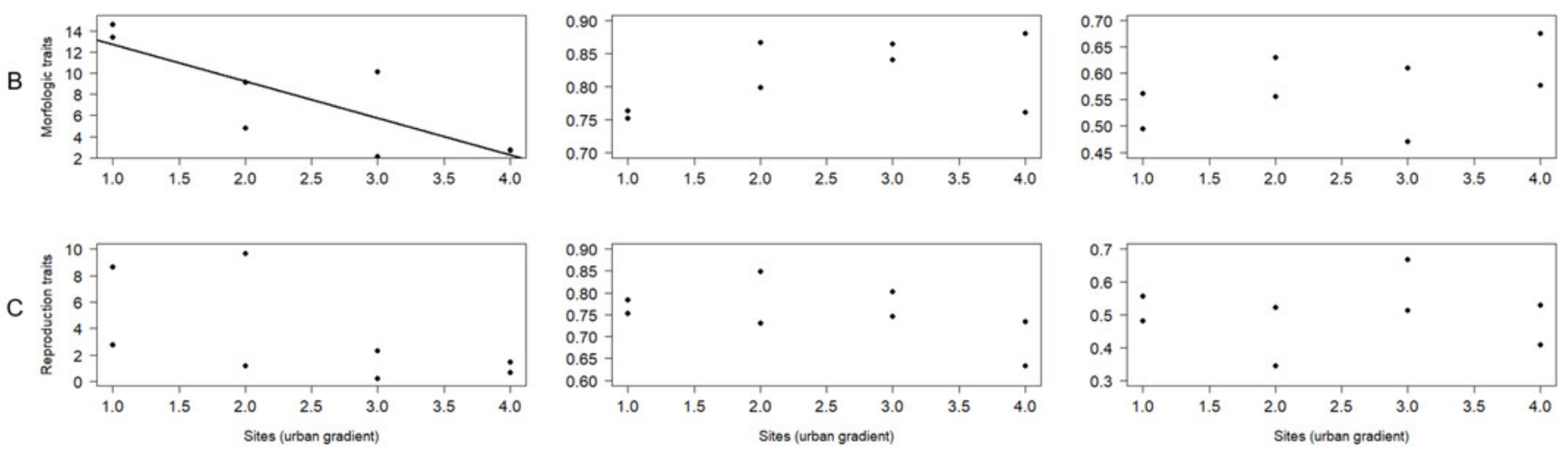
Figure 4

Linear regression analysis between functional richness (FRic), functional divergence (FDiv), functional evenness (FEve), and urbanization variables.
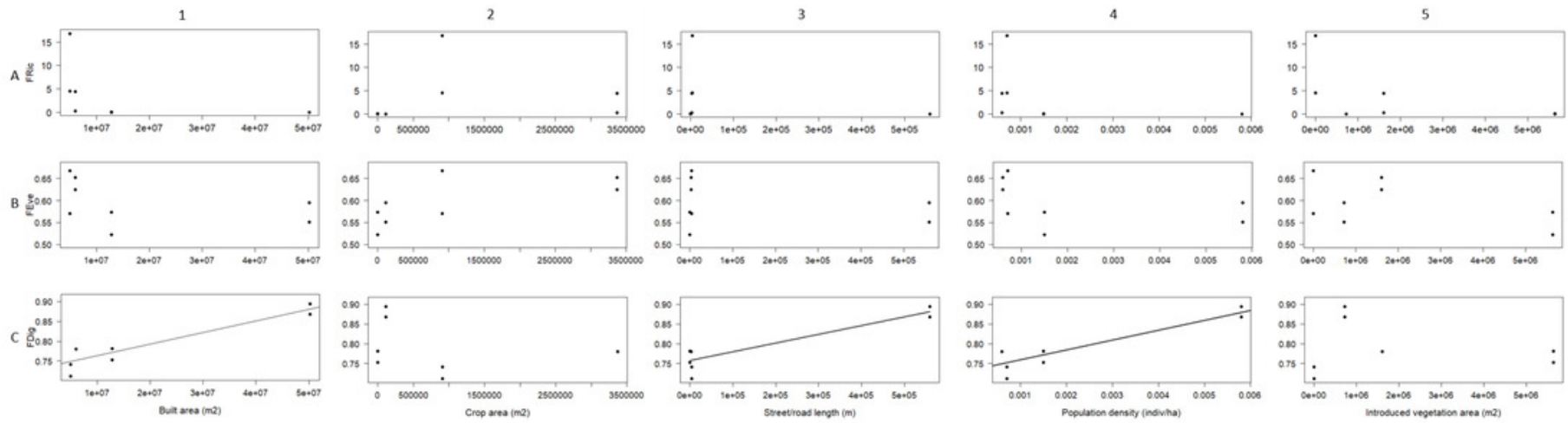
Figure 5

Polynomial regression analysis between the functional-value index and macromycete species richness.

Dots represent every plot in the study area.

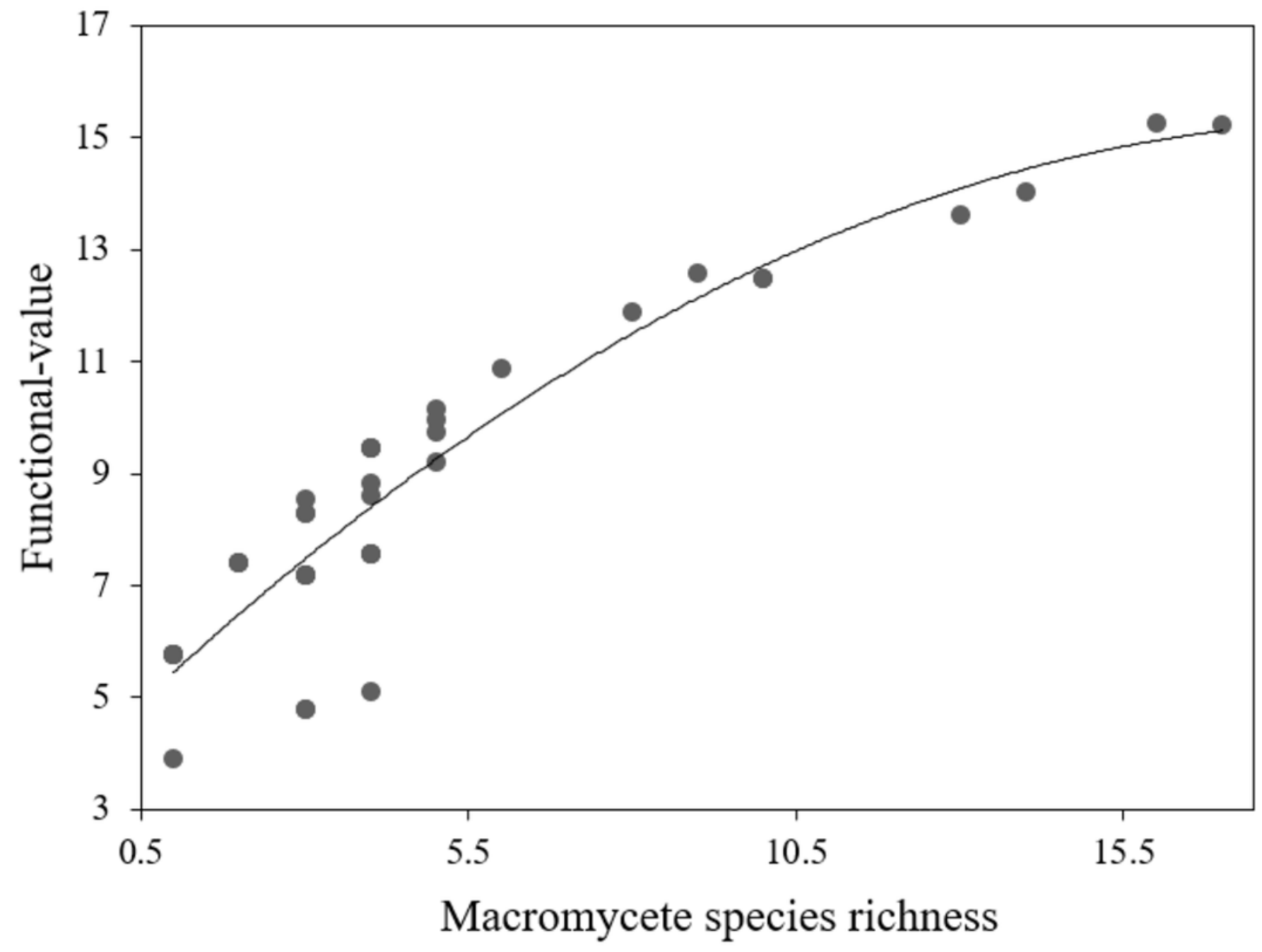




\section{Table $\mathbf{1}$ (on next page)}

Spearman's rho coefficients $(\rho)$. Correlation between macromycete species richness and explanatory variables. 
Table 1. Spearman's rho coefficients $(\rho)$. Correlation between macromycete species richness and explanatory variables.

\begin{tabular}{llc}
\hline Variable & $\rho$ & $p$-value \\
\hline Slope* & 0.317 & 0.045 \\
Aspect & 0.101 & 0.532 \\
Stoniness cover** & -0.433 & 0.005 \\
Soil cover* & -0.375 & 0.016 \\
Litter depth*** & 0.578 & $<0.0001$ \\
Air temperature*** & -0.569 & 0.0001 \\
Soil temperature*** & -0.732 & $<0.0001$ \\
Air humidity* & 0.359 & 0.022 \\
Soil humidity* & 0.644 & $<0.0001$ \\
Tree density & -0.147 & 0.363 \\
Mean tree height * & 0.390 & 0.012 \\
Basal area & 0.277 & 0.082 \\
\hline
\end{tabular}

$* p<0.05, * * p<0.01, * * * p<0.001$ 